\title{
Egyptian consensus on treat-to-target approach for osteoporosis: a clinical practice guideline from the Egyptian Academy of bone health and metabolic bone diseases
}

Yasser El Miedany ${ }^{1,2^{*}}$ (D) Mohammed Hassan Abu-Zaid ${ }^{3}$ (D), Maha El Gaafary ${ }^{4}$, Mona Mansour Hasab El Naby ${ }^{5}$, Nihal Fathi ${ }^{6}$, Heba Gamal Saber ${ }^{7}$ (D), Waleed Hassan ${ }^{8}$, Mervat Eissa ${ }^{9}$ (D) Nevine Mohannad ${ }^{10}$, Henaz Khaled ${ }^{5}$ (D), Mohamed Mortada ${ }^{11}$, Samah Ismail Nasef ${ }^{12}$, Salwa Galal ${ }^{5}$, Rasha Ghaleb ${ }^{13}$, Samar Abd Alhamed Tabra ${ }^{3}$, Sally S. Mohamed ${ }^{9}$, Basma M. Medhat ${ }^{9}$ (D) , Hany M. Aly ${ }^{14}$ (D) Gehan Elolemy $^{8}$ (D) Nermeen Ahmed Fouad ${ }^{15}$, Sahar S. Ganeb ${ }^{16}$ (D) Yasmin Adel ${ }^{17}$ (D) Medhat Mohiy Eldin Ibrahim ${ }^{18}$, Osama Farouk ${ }^{19}$ and Naglaa Gadallah ${ }^{5}$

\footnotetext{
Abstract

Background: This study was carried out to achieve an Egyptian expert consensus on a treat-to-target management strategy for osteoporosis using Delphi technique. A scientific committee identified researchers and clinicians with expertise in osteoporosis in Egypt. Delphi process was implemented (2 rounds) to establish a consensus on 15 clinical standards: (1) concept, (2) diagnosis, (3) case identification, (4) whom to treat, (5) who should treat?, (6) case stratification and intervention thresholds, (7) falls risk, (8) investigations, (9) treatment target, (10) management, (11) optimum treatment duration, (12) monitoring, (13) drug holiday, (14) osteoporosis in men, and (15) post-fracture care and fracture liaison service.

Results: The surveys were sent to an expert panel $(n=25)$, of whom 24 participated in the two rounds. Respondents were drawn from different governorates and health centres across Egypt including the Ministry of Health. Most of the participants were rheumatologists (76\%), followed by internists (8\%), orthopaedic doctors (4\%), rehabilitation doctors (4\%), primary care (4\%), and ortho-geriatrics (4\%) physicians. Seventy-two recommendations, categorised into 15 sections, were obtained. Agreement with the recommendations (rank 7-9) ranged from 83.4 to $100 \%$. Consensus was reached (i.e. $\geq 75 \%$ of respondents strongly agreed or agreed) on the wording of all 15 clinical standards identified by the scientific committee. An algorithm for the management of postmenopausal osteoporosis has been suggested.

(Continued on next page)
}

\footnotetext{
* Correspondence: miedanycrd@yahoo.com

${ }^{1}$ Rheumatology and Rehabilitation, Ain Shams University, Cairo, Egypt

${ }^{2}$ King's College London, London, UK

Full list of author information is available at the end of the article
}

\section{Springer Open}

(-) The Author(s). 2021 Open Access This article is licensed under a Creative Commons Attribution 4.0 International License, which permits use, sharing, adaptation, distribution and reproduction in any medium or format, as long as you give appropriate credit to the original author(s) and the source, provide a link to the Creative Commons licence, and indicate if changes were made. The images or other third party material in this article are included in the article's Creative Commons licence, unless indicated otherwise in a credit line to the material. If material is not included in the article's Creative Commons licence and your intended use is not permitted by statutory regulation or exceeds the permitted use, you will need to obtain permission directly from the copyright holder. To view a copy of this licence, visit http://creativecommons.org/licenses/by/4.0/. 
(Continued from previous page)

Conclusion: A wide and representative panel of experts established a consensus regarding the management of osteoporosis in Egypt. The developed guidelines provide a comprehensive approach to the assessment and management of osteoporosis for all Egyptian healthcare professionals who are involved in its management.

Keywords: Delphi, Consensus, Guidelines, Egypt, Osteoporosis, Standards of care, Very high fracture risk, Bisphosphonates, Denosumab, Romosozumab, Egyptian Academy of bone health

\section{Background}

Postmenopausal osteoporosis is common, characterised by decreased bone strength, with a high possibility of sustaining a consequent fragility fracture [1]. Since the bones get more porous, breaking occurs even from lowlevel impact or stress that would not normally break a healthy bone. Fractures are not only associated with increased mortality, but also with increased burden to the health care system. Furthermore, fractures can cause pain and have negative impact on the patients' mobility, function, and quality of life. In several cases, fractures may also induce a state of fear of falling [2-5]. Those who sustain a fracture are at high risk of developing subsequent fractures [6]. This additional risk of refracture is highest immediately after a fracture [7]. This paved the way to the new concept of imminent fracture risk which highlights a state of relative emergency in patients with osteoporosis. The presence of an imminent risk period signals that there is an opportunity to optimise the benefits of fracture prevention treatments if patients could be identified and managed as soon as possible after fracture.

The clinical relevance of osteoporosis lies in the associated fragility fractures; until such an event occurs, there are usually no symptoms [8]. Epidemiological studies, in the Western world, revealed that one in three postmenopausal women and 1 in 5 men above 50 years of age will have an osteoporotic fracture in their lifetime [1]. The prevalence of osteoporosis is relatively high amongst the Egyptian population and is associated with a wide range of risk factors and medical conditions [9]. Based on different studies, carried out in Egypt, it has been estimated that $53.9 \%$ of postmenopausal women have osteopaenia and $28.4 \%$ have osteoporosis [10]. On the men side, earlier data revealed that $26 \%$ of men have osteopaenia and $21.9 \%$ have osteoporosis $[10,11]$. In another study, Salem et al. [12] reported that $16.7 \%$ of 1190 Egyptian postmenopausal females had lumbar osteoporosis, whilst in another study carried out at the Trauma Unit of Assiut University Hospital, Egypt, the prevalence of OP was high (74.9\%) in patients admitted with hip fractures [13]. In spite of the finding that osteoporosis awareness has increased in the last 20 years with the introduction of several effective pharmaceutical agents for treating those at high risk [14], it was rated as moderate amongst Egyptian women particularly with regards to its risk factors, preventive measures and consequences [11].

Similar to several other chronic diseases, such as diabetes mellitus, hypertension, hyperlipidaemia, and rheumatoid arthritis, where well-established treatment goals have been set up with a consequent adjustment of the disease medical management [15], there has been a move to a more goaloriented, patient-centred approach to osteoporosis treatment. Establishing a more personalised, goal-directed approach to managing osteoporosis may foster better drug therapy selection, improve patient follow-up, and anticipate the use of new treatments [16]. The treat-to-target (T2T) (goal-directed therapy) strategy has been suggested as an approach to assist clinicians in selecting the most appropriate initial treatment for osteoporosis and guiding subsequent decisions to continue, change, or stop treatment [17].

Bearing all these factors in mind, the development of a comprehensive approach to yield consensus amongst experts in osteoporosis would be the best approach for establishing a T2T strategy and for assessing its application in standard clinical practice in Egypt. The work was organised by the Egyptian Academy of bone health and metabolic bone diseases aiming at achieving an Egyptian expert consensus on a treat-to-target (T2T) management strategy in osteoporosis using Delphi technique.

\section{Methods \\ Design}

A qualitative synthesis of scientific evidence and consensus based on clinical experience and existing scientific evidence was used to formulate the study design

\section{Development stages \\ Scientific committee}

Preparation began with the establishment of a scientific committee that was composed of five experts in bone metabolism. The project is an initiative led by the Egyptian Academy of bone health and bone metabolism to set up a gold standard for osteoporosis management in Egypt. The scientific committee reached a consensus on the essential contents to include in the document. Two experts were appointed to be responsible for a literature review which was conducted with the assistance of an expert in methodology. Following the revision, each of the experts responsible for the literature review provided recommendations 
regarding each section based on evidence, when that was available, or on their own experience. The level of evidence was determined for each section using the Oxford Centre for Evidence-Based Medicine (CEBM) system. For this purpose, both a rheumatologist and an expert in methodology provided guidance. The scientific committee considered the identification of the study participants (expert panel) and assisted in drawing up, reviewing, and approving the specific questionnaire developed for use during the Delphi rounds. Its members likewise validated and analysed the results of the study.

\section{Key questions used to develop the guideline}

This guideline was based on a series of structured key questions that define the target population, the intervention, diagnostic test, or exposure under investigation, the comparison(s) used and the outcomes used to measure efficacy, effectiveness, or risk. These questions form the basis of the systematic literature search and consequently the clinical care standards. The key questions are shown in Table 1.

\section{Developing the clinical care standards framework}

Based on the answers to the structured key questions and the literature review, a structured template was developed to facilitate standardised identification of guideline components. For each guideline component, the format in which the recommendations/information will be provided and extracted have been identified.

Table 1 Key questions used to develop the guideline

-Who is at risk?

-What factors contribute to increased fracture risk/increased number of fractures?

-What is the best approach to case identification?

- Is there an approach for case stratification?

- Which diagnostic measurements or tools are effective in identifying increased risk of fracture?

- Which diagnostic methods or tools best predict response to pharmacological treatment?

-Who should treat osteoporosis?

- Which pharmacological interventions are effective in fracture prevention?

- For individuals prescribed pharmacological interventions, what is the optimal duration of treatment?

- Which type of monitoring should be conducted in individuals taking pharmacological interventions?

- What lifestyle interventions are effective in reducing the risk of fracture or improving BMD levels?

- What interventions are effective in improving adherence to the pharmacological interventions for fracture prevention? (drug administration route (oral vs parenteral), follow-up (specialist-led clinics, regular review, support groups), patient information)

- What is the clinical and cost-effectiveness of treat-to-target model of care

(which include assessment, identification, treatment, and follow-up)?

- Management of osteoporosis in men

- Best approach to post-fracture care

\section{Expert panel}

The scientific committee nominated 25 participants. The criteria for their selection included professional knowledge and experience (at least 8 years of experience) in the field of osteoporosis, its management and practice in the Egyptian Health System, and active participation in scientific research on osteoporosis.

\section{Delphi process}

The Delphi technique is a structured method widely used to gather important information on a specific topic. It relies on the key assumption that forecasts from a group are generally more accurate than those from individuals. Therefore, the aim of the Delphi method is to construct consensus forecasts from a group of experts in a structured iterative manner. Its methodology is based on a series of questionnaires or 'rounds' addressed to experts. The Delphi method generally involves the following stages: (1) a panel of experts is assembled; (2) forecasting tasks/challenges are set and distributed to the experts; (3) experts return initial forecasts and justifications, and these are compiled and summarised in order to provide feedback; (4) feedback is provided to the experts, who now review their forecasts in light of the feedback, and this step may be iterated until a satisfactory level of consensus is reached; and (5) final forecasts are constructed by aggregating the experts' forecasts. The key features of this method are the anonymity of participants and controlled feedback [18-20].

\section{Consensus process}

Two Delphi rounds were carried out to establish consensus regarding the T2T strategy in osteoporosis. Once the main aspects of this strategy were identified, a discussion group has defined the aspects to be included in the questionnaire with the scientific committee. The structured Delphi approach ensures that the opinions of participants are equally considered, and it is particularly useful for geographically diverse centres as in Egypt. The Delphi process was conducted through online questionnaires. The first round of the electronic questionnaire included 61 items involved in the T2T strategy on osteoporosis.

\section{Voting process}

Live online-delivered voting was carried out in 2 rounds that were strictly time-limited. All members of the task force were invited to participate and were pre-informed of the time of opening and closure of each round of votes. Unique access links were sent out, and anonymous votes were gathered and processed. Comments on re-phrasing, potential ambiguity, and unidentified overlaps were gathered regarding each statement at the same 
time in the voting process. Only the members of the task force had the right to vote on the statements.

\section{Rating}

Each statement was rated between 1 and 9 with 1 being 'complete disagreement' and 9 being 'complete agreement'. Generally, 1-3, 4-6, and 7-9 represent disagreement, uncertainty, and agreement, respectively. There is no requirement to vote on all statements, and the members are encouraged to abstain if they feel that a statement falls outside their area of expertise. Therefore, an 'uncertainty' vote represents 'inconvenience about the accuracy of the recommendation'. All statements are allowed for the entry of comments which were reviewed by the scientific committee after each round of voting. In the second round of votes, the members were further urged to leave comments wherever they vote a disagreement. This will enable the panel to identify an instance of misinterpretation of statement and invalidate the vote on that statement.

\section{Definition of consensus}

Definition of consensus was established before data analyses. It was determined that consensus would be achieved if at least $75 \%$ of participants reached agreement (score 7-9) or disagreement (score 1-3) [19-22]. A statement was retired if it had a mean vote below 3 or a 'low' level of agreement. Statements whose rate came in the uncertainty score (4-6) were revised in view of the comments. The levels of agreement on each statement of recommendation were defined as 'high' if after the second round of votes, all votes on a statement fell into the agreement bracket (7-9).

\section{Chronogram of Delphi rounds}

The first round took place between 14 and 18 November 2020 (5 days). The aspects about which respondents did not reach consensus in this first round were revised in view of the comments and included in the second round. The second round took place ( 1 week after the first round) and remained for 3 days, between 20 and 22 November 2020.

\section{Ethical aspects}

This study was performed in accordance with the Helsinki Declaration. Ethics approval was deemed unnecessary according to national regulations. As per the Egyptian National Ethical Committee regulations, verbal informed consent was required from all the participants included in the study. All the participants were dissociated from the results and kept anonymous, in compliance with data protection regulations

\section{Results}

\section{Participants' characteristics}

The surveys were sent to an expert panel $(n=25)$, of whom 24 (96\%) participated in the two rounds. Respondents were drawn from different governorates and health centres across Egypt: Ministry of Health (4\%), Cairo University $12.5 \%$, Ain Shams University (20\%), Tanta University (8\%), Benha University (12.5\%), Alexandria University (4\%), Suez Canal University (4\%), Zagazig University (4\%), Minia University (4\%), Mansoura University (4\%), Fayoum University (4\%), Azhar University (4\%), and Assiut University (8\%). Most of the participants were specialised in rheumatology (76\%), followed by internal medicine $(8 \%)$, orthopaedic surgery $(4 \%)$, rehabilitation (4\%), primary care (4\%), and ortho-geriatrics (4\%).

\section{Clinical care standards framework}

At the end of round 2, a total of seventy-two (72) recommendations, categorised into fifteen sections of standard of care, were obtained. A breakdown is presented in Table 2. Stratification of these recommendations is as follows:

- Concept: 2 elements

- Diagnosis: 2 elements

- Case identification: 4 elements

- Whom to treat: 2 elements

- Who should treat: 1 element

- Case stratification: 6 elements

- Falls: 1 element

- Treat-to-target: 1 element

- Investigations: 2 elements

- Management: 28 elements

- Optimum treatment duration: 5 elements

- Monitoring: 12 elements

- Drug holiday: 4 elements

- Men: 8 elements

- Fracture liaison service: 2 elements

Table 3 shows anti-fracture efficacy of the approved treatments for postmenopausal women with osteoporosis when given with calcium and vitamin $\mathrm{D}$, whereas Table 4 shows the effect of approved interventions for glucocorticoid-induced osteoporosis on BMD and fracture risk

\section{Round 1}

The response rate for round 1 was 96\% (24/25). Consensus was reached on the inclusion of clinical standards on $80.3 \%$ of the components (i.e. $\geq 75 \%$ of respondents strongly agreed or agreed). There were comments raised regarding the wording of some of the recommendations namely the proactive case identification based on common risk factors, although consensus was reached. The 
Table 2 Breakdown of statements of recommendations, its individual rank, and level of agreement

\begin{tabular}{|c|c|c|c|c|c|}
\hline No. & Standard & Statement & LE & Mean rate \pm SD & $\begin{array}{l}\text { Level of } \\
\text { agreement }\end{array}$ \\
\hline 1 & I. Concept: Who is at risk? & $\begin{array}{l}\text { Early diagnosis and assessment of fracture risks and } \\
\text { optimum management of preventable fracture risk } \\
\text { factors through optimum fracture liaison service is very } \\
\text { effective in the management of osteoporosis }\end{array}$ & $2 a$ & $8.92 \pm 0.282$ & $\mathrm{H}$ \\
\hline 2 & & $\begin{array}{l}\text { Fracture liaison services improve outcomes of } \\
\text { osteoporosis-related fractures and reductions in re- } \\
\text { fracture incidence and mortality }\end{array}$ & $2 a$ & $8.83 \pm 0.482$ & $\mathrm{H}$ \\
\hline 3 & II. Diagnosis & $\begin{array}{l}\text { BMD testing is the gold standard in diagnosing } \\
\text { osteoporosis and can be considered to stratify the } \\
\text { patients according to their fracture risk }\end{array}$ & $1 a$ & $8.67 \pm 0.637$ & $\mathrm{H}$ \\
\hline 4 & & $\begin{array}{l}\text { Diagnostic assessment of individuals with osteoporosis } \\
\text { should include not only the assessment of BMD but } \\
\text { also the exclusion of diseases that mimic osteoporosis, } \\
\text { elucidation of the cause of the osteoporosis, and the } \\
\text { management of any associated morbidity }\end{array}$ & $2 a$ & $8.88 \pm 0.338$ & $\mathrm{H}$ \\
\hline 5 & III. Case identification & $\begin{array}{l}\text { FRAX is an important web-based tool in the assessment } \\
\text { of fragility fracture risk in osteoporosis and should be } \\
\text { used to stratify the patients according to their fracture } \\
\text { risk }\end{array}$ & $1 a$ & $8.83 \pm 0.482$ & $\mathrm{H}$ \\
\hline 6 & & $\begin{array}{l}\text { It is advisable to calculate the FRAX score according to } \\
\text { the validated Egyptian measures }\end{array}$ & $1 a$ & $8.96 \pm 0.204$ & $\mathrm{H}$ \\
\hline 7 & & $\begin{array}{l}\text { If no Egyptian measures are available, the FRAX can be } \\
\text { calculated according to regional validated measures }\end{array}$ & $1 a$ & $8.83 \pm 0.597$ & $\mathrm{H}$ \\
\hline 8 & & $\begin{array}{l}\text { Adjustment of the conventional FRAX estimates of } \\
\text { probabilities of hip fracture and a major osteoporotic } \\
\text { fracture should be carried out to modulate the risk } \\
\text { assessment whenever appropriate }\end{array}$ & $2 b$ & $8.38 \pm 0.875$ & $\mathrm{H}$ \\
\hline 9 & Whom to treat & $\begin{array}{l}\text { Postmenopausal women at high risk of fractures, } \\
\text { especially those who have experienced a recent } \\
\text { fracture should be assessed for osteoporosis } \\
\text { (assessment and management of any other cofactors or } \\
\text { comorbidities that aggravates patients fracture risks } \\
\text { should be considered) }\end{array}$ & $2 a$ & $8.92 \pm 0.408$ & $\mathrm{H}$ \\
\hline 10 & & $\begin{array}{l}\text { Women and men with a } T \text { score in the osteopenic } \\
\text { range ( } T \text { score }-1 \text { to }-2.5) \text { may still need treatment if } \\
\text { they have been identified to have a high or very high } \\
\text { fracture risk }\end{array}$ & $2 b$ & $8.63 \pm 0.824$ & $\mathrm{H}$ \\
\hline 11 & $\begin{array}{l}\text { Who should treat } \\
\text { osteoporosis }\end{array}$ & $\begin{array}{l}\text { Several specialists have the experience in managing } \\
\text { osteoporosis including rheumatology, geriatric, ortho- } \\
\text { geriatric medicine, and endocrinology. For a healthcare } \\
\text { practitioner to be recognised as osteoporosis specialist, } \\
\text { he/she should be (1) Working in National/University } \\
\text { Hospital/Ministry of Health hospital with regular meet- } \\
\text { ings and provided services. 2) In solo practice if less } \\
\text { than } 3 \text { years, a log book showing traceable manage- } \\
\text { ment and outcome management over } 3 \text { years. And if } \\
\text { practice more than } 3 \text { years, the specialist should pro- } \\
\text { vide an audit comparing his service with gold stan- } \\
\text { dards as national guidelines for the treatment of } \\
\text { osteoporosis showing the outcome of his service. (3) } \\
\text { Preferable if healthcare professional have publications } \\
\text { in peer-reviewed journal whether national or } \\
\text { international }\end{array}$ & 5 & $8.38 \pm 1.056$ & $\mathrm{H}$ \\
\hline 12 & $\begin{array}{l}\text { Case stratification and } \\
\text { intervention thresholds }\end{array}$ & $\begin{array}{l}\text { Patients should be stratified according to their risk of } \\
\text { fracture, low, moderate, high, and very high risk }\end{array}$ & $2 b$ & $8.75 \pm 0.608$ & $\mathrm{H}$ \\
\hline 13 & & $\begin{array}{l}\text { 'Low risk' includes no prior hip or spine fractures, a } \\
\text { BMD } T \text { score at the hip and spine both above }-1.0 \text {, } \\
\text { and } 10 \text {-year hip fracture risk }<1 \% \text { and } 10 \text {-year risk of } \\
\text { major osteoporotic fractures }<10 \%\end{array}$ & $2 b$ & $8.46 \pm 0.932$ & $\mathrm{H}$ \\
\hline 14 & & 'Moderate risk' includes no prior hip or spine fractures, & $2 b$ & $8.46 \pm 0.932$ & $\mathrm{H}$ \\
\hline
\end{tabular}


Table 2 Breakdown of statements of recommendations, its individual rank, and level of agreement (Continued)

\begin{tabular}{|c|c|c|c|c|c|}
\hline No. & Standard & Statement & LE & Mean rate \pm SD & $\begin{array}{l}\text { Level of } \\
\text { agreement }\end{array}$ \\
\hline & & $\begin{array}{l}\text { a BMD T-score at the hip and spine both between }-1 \\
\text { and }-2.5 \text {, or } 10 \text {-year hip fracture risk }<3 \% \text { or risk of } \\
\text { major osteoporotic fractures }<20 \%\end{array}$ & & & \\
\hline 15 & & $\begin{array}{l}\text { 'High risk' includes a prior spine or hip fracture, or a } \\
\text { BMD T score at the hip or spine of }-2.5 \text { or below, or } \\
10 \text {-year hip fracture risk }>3 \% \text {, or risk of major osteopor- } \\
\text { otic fracture risk }>20 \%\end{array}$ & 1 & $8.63 \pm 0.824$ & $\mathrm{H}$ \\
\hline 16 & & $\begin{array}{l}\text { Very high risk' includes multiple spine fractures and a } \\
\text { BMD T score at the hip or spine of }-2.5 \text { or below }\end{array}$ & $2 a$ & $8.54 \pm 0.932$ & $\mathrm{H}$ \\
\hline 17 & & $\begin{array}{l}\text { Very high fracture risk patients should be treated only } \\
\text { by a specialist in osteoporosis management. }\end{array}$ & $2 b$ & $8.79 \pm 0.509$ & $\mathrm{H}$ \\
\hline 18 & Falls risk & $\begin{array}{l}\text { Falls risk should be assessed for every patient evaluated } \\
\text { for fracture risk }\end{array}$ & $2 a$ & $8.63 \pm 0.77$ & $\mathrm{H}$ \\
\hline 19 & Treat-to-target & $\begin{array}{l}\text { Treatment target: } T \text { score }>-1.5 \text {; fracture risk below } \\
\text { the treatment threshold or FRAX major osteoporosis } \\
\text { fracture probability }<10 \% \text {, hip fracture risk probability } \\
<3 \% \text {; fracture-free interval of } 3 \text { to } 5 \text { years }\end{array}$ & $2 b$ & $8.38 \pm 0.992$ & $\mathrm{H}$ \\
\hline 20 & Investigations & $\begin{array}{l}\text { Clinical: height should be measured every 1-2 years in } \\
\text { adults } \geq 50 \text { years of age } \\
\text { Biochemical tests: } \\
\text { Bone profile: calcium, alkaline phosphatase, eGFR, } \\
\text { creatinine } \\
\text { Whenever indicated: } \\
\text { - } 25 \text {-hydroxyvitamin D: symptoms of vitamin D } \\
\text { deficiency } \\
\text { - Parathyroid hormone (PTH): persistent hypercalcaemia } \\
\text { - Serum testosterone, LH, FSH and SHBG, PSA (men) } \\
\text { - 24-h urinary cortisol/dexamethasone suppression test } \\
\text { - Endomysial and/or tissue transglutaminase antibodies } \\
\text { (coeliac disease) }\end{array}$ & $2 a$ & $8.58 \pm 0.776$ & $\mathrm{H}$ \\
\hline 21 & & $\begin{array}{l}\text { Radiological: } \\
\text { Assessment for presence of vertebral fracture(s) either by: } \\
\text { - X-ray, } \\
\text { - DXA-based Vertebral fracture assessment (VFA), or } \\
\text { - Other radiological investigations such as CT or MRI are } \\
\text { of value particularly for vertebral fracture assessment }\end{array}$ & $2 a$ & $8.58 \pm 0.776$ & $\mathrm{H}$ \\
\hline 22 & Management & $\begin{array}{l}\text { Patient education/group therapy can be of value in } \\
\text { osteoporosis management. Shared decision-making } \\
\text { tools might be a preferable option to ensure patient } \\
\text { compliance and adherence to therapy }\end{array}$ & 1 & $8.59 \pm 0.775$ & $\mathrm{H}$ \\
\hline 23 & & $\begin{array}{l}\text { Lifestyle measures that are very important in improving } \\
\text { bone health include increasing levels of physical activity } \\
\text { and perform weight-bearing exercise, stopping smoking } \\
\text { and alcohol intake, reducing the risk of falls, care for other } \\
\text { relevant comorbidities as renal or ischaemic cardiovascu- } \\
\text { lar diseases, considering hip protectors, and ensuring ad- } \\
\text { equate dietary calcium intake and vitamin D status }\end{array}$ & 1 & $8.63 \pm 0.711$ & $\mathrm{H}$ \\
\hline 24 & & $\begin{array}{l}\text { Exercise is important for managing osteoporosis, with } \\
\text { appropriate safety precautions }\end{array}$ & $2 \mathrm{a}$ & $8.54 \pm 0.779$ & $\mathrm{H}$ \\
\hline 25 & & $\begin{array}{l}\text { Every patient should be taking calcium ( } 1 \mathrm{~g} / \text { day }) \text { and } \\
\text { vitamin D ( } 1000 \mathrm{IU} / \text { day) supplement therapy in addition } \\
\text { to the osteoporosis medication. The dose can be } \\
\text { adjusted to the patient-associated comorbidities. The } \\
\text { vitamin D dose should also be adjusted according to } \\
\text { the serum vitamin D level }\end{array}$ & 1 & $8.55 \pm 0.932$ & $\mathrm{H}$ \\
\hline 26 & & $\begin{array}{l}\text { Oral bisphosphonates (alendronate, risedronate) are } \\
\text { first-line treatments in the majority of osteoporosis } \\
\text { cases. Ibandronate is not recommended to reduce non- } \\
\text { vertebral or hip fracture risk }\end{array}$ & 1 & $8.08 \pm 1.316$ & $\mathrm{H}$ \\
\hline 27 & & Patients aged $\geq 65$ years with osteopaenia ( $T$ score & $2 b$ & $8.67 \pm 0.761$ & $\mathrm{H}$ \\
\hline
\end{tabular}


Table 2 Breakdown of statements of recommendations, its individual rank, and level of agreement (Continued)

\begin{tabular}{ll}
\hline No. Standard & Statement \\
\hline & from -1 to -2.5 at either the total hip or the femoral \\
& neck on either side) who have moderate risk of fracture \\
& $(10$-year fracture probability at the hip in the range of \\
& $1-3 \%$ and $10-20 \%$ at the spine) can be eligible to \\
receive prophylactic treatment zoledronic acid 5 mg IV \\
every 18 months for 4 doses
\end{tabular}

In osteoporotic women who are intolerant of oral bisphosphonates or in whom they are contraindicated; intravenous bisphosphonates or denosumab provide the most appropriate alternatives as initial therapy (with raloxifene or hormone replacement therapy as additional options); however, this should be decided and prescribed by osteoporosis specialist

Oral and intravenous bisphosphonates are contraindicated in patients with hypocalcaemia, hypersensitivity to bisphosphonates, and severe renal impairment (eGFR $\leq 35 \mathrm{ml} / \mathrm{min}$ for alendronate and zoledronic acid and $\leq 30 \mathrm{ml} / \mathrm{min}$ for other bisphosphonates). Pregnancy and lactation are also contraindications. Oral bisphosphonates are contraindicated in people with abnormalities of the oesophagus that delay oesophageal emptying such as stricture or achalasia, and inability to stand or sit upright for at least 30-60 min. They should be used with caution in patients with other upper gastrointestinal disorders. Pre-existing hypocalcaemia must be investigated and, where due to vitamin D deficiency, treated with vitamin $\mathrm{D}$ before treatment is initiated. only by osteoporosis specialist when used for osteoporosis management. constituents of the formulation. Its use is not recommended in pregnancy or in the paediatric population (age $\leq 18$ years). to each dose of denosumab and within 2 weeks after the initial dose in patients predisposed to hypocalcaemia (e.g. patients with severe renal impairment, creatinine clearance $\leq 30 \mathrm{ml} / \mathrm{min}$ ) or if suspected symptoms of hypocalcaemia occur or if otherwise indicated. Patients should be advised to report symptoms of hypocalcaemia. are intolerant to bisphosphonates and denosumab can be considered for HRT or SERM

- If with vasomotor symptoms and low cancer breast risk, HRT can be used

- If no uterus: oestrogen

- If uterus is present: oestrogen + progesterone

- If without vasomotor symptoms and high cancer breast risk, SERM should be used high risk of fracture, particularly those with history of osteoporotic vertebral fracture, sequential therapy can be adopted with teriparatide treatment up to 2 years is recommended then continue with anti-resorptive drug (bisphosphonates or denosumab). This should be decided and prescribed by osteoporosis specialist 
Table 2 Breakdown of statements of recommendations, its individual rank, and level of agreement (Continued)

\begin{tabular}{|c|c|c|c|c|c|}
\hline No. & Standard & Statement & LE & Mean rate \pm SD & $\begin{array}{l}\text { Level of } \\
\text { agreement }\end{array}$ \\
\hline & & $\begin{array}{l}\text { postmenopausal women who are at very high risk for } \\
\text { fracture particularly those who have past history of hip } \\
\text { or vertebral fractures. This should be decided and } \\
\text { prescribed by osteoporosis specialist }\end{array}$ & & & \\
\hline 36 & & $\begin{array}{l}\text { After stopping long-term denosumab therapy, patients } \\
\text { should be switched to another antiresorptive agent to } \\
\text { maintain the benefit achieved with denosumab ( } 1 \text { dose } \\
\text { of zoledronic acid given } 7-8 \text { months after the last } \\
\text { denosumab dose (another IV zolerdronate dose may be } \\
\text { considered in } 1 \text { year) or oral bisphosphonate starting } 6 \\
\text { months after the last dose of denosumab for } 12-24 \\
\text { months may be the preferred clinical strategy) }\end{array}$ & $2 a$ & $8.67 \pm 0.799$ & $\mathrm{H}$ \\
\hline 37 & & $\begin{array}{l}\text { Combination therapy of parathyroid hormone and } \\
\text { denosumab can be considered in very high fracture risk } \\
\text { patients. This should be considered on an individual } \\
\text { basis; patients should be assessed and managed by } \\
\text { osteoporosis specialist }\end{array}$ & $2 \mathrm{~b}$ & $8.38 \pm 1.056$ & $\mathrm{H}$ \\
\hline 38 & & $\begin{array}{l}\text { In postmenopausal women with osteoporosis at high } \\
\text { risk of fracture and (with a low risk of deep vein } \\
\text { thrombosis and bisphosphonates or denosumab are } \\
\text { not appropriate, or with a high risk of breast cancer), } \\
\text { raloxifene may be an option }\end{array}$ & $2 b$ & $8.58 \pm 0.776$ & $\mathrm{H}$ \\
\hline 39 & & $\begin{array}{l}\text { It is important that osteoporotic patients should always } \\
\text { be counselled regarding treatment compliance and any } \\
\text { side effects at } 3 \text { months after initiating therapy and } \\
\text { then on yearly basis }\end{array}$ & $2 a$ & $8.71 \pm 0.624$ & H \\
\hline 40 & & $\begin{array}{l}\text { In patients with dental disease or other risk factors (e.g. } \\
\text { glucocorticoids, tobacco use), dental examination with } \\
\text { preventive dentistry is recommended prior to } \\
\text { treatment with oral or intravenous bisphosphonates }\end{array}$ & $2 a$ & $8.42 \pm 1.101$ & $\mathrm{H}$ \\
\hline 41 & & $\begin{array}{l}\text { Whilst on bisphosphonate or denosumab therapy, patients } \\
\text { should avoid invasive dental procedures if possible }\end{array}$ & $2 b$ & $8.75 \pm 0.608$ & $\mathrm{H}$ \\
\hline 42 & Optimum treatment duration & $\begin{array}{l}\text { Bisphosphonate treatment should last for } 3-5 \text { years ( } 3 \\
\text { years for zoledronic acid and } 5 \text { years for alendronate } \\
\text { and risedronate) can generally be recommended. } \\
\text { Continuation of oral bisphosphonate (alendronate and } \\
\text { risedronate) treatment beyond } 5 \text { years can generally be } \\
\text { recommended in the following situations: } \\
\text { - Age } \geq 75 \text { years } \\
\text { - Previous history of a hip or vertebral fracture } \\
\text { - Current treatment with oral glucocorticoids } \geq 7.5 \mathrm{mg} \\
\text { prednisolone/day or equivalent } \\
\text { - Occurrence of one or more low trauma fractures } \\
\text { during treatment, after exclusion of poor adherence } \\
\text { to treatment (e.g. less than } 80 \% \text { of treatment has } \\
\text { been taken) and after causes of secondary } \\
\text { osteoporosis have been excluded. In such cases, class } \\
\text { switching may be considered }\end{array}$ & $2 a$ & $8.46 \pm 0.833$ & $\mathrm{H}$ \\
\hline 43 & & Denosumab therapy should initially last for 5 years & $2 a$ & $8.5 \pm 0.885$ & $\mathrm{H}$ \\
\hline 44 & & $\begin{array}{l}\text { Whenever indicated, the following therapies can be } \\
\text { continued for: } \\
.10 \text { years_alendronic acid and denosumab } \\
.7 \text { years—risendronic acid } \\
.3 \text { years_zolendronic acid }\end{array}$ & 1 & $8.75 \pm 0.676$ & $\mathrm{H}$ \\
\hline 45 & & $\begin{array}{l}\text { Parathyroid hormone therapy } 20 \mu \mathrm{g} \text { daily for a } \\
\text { maximum duration of treatment of } 24 \text { months (course } \\
\text { not to be repeated) }\end{array}$ & $2 a$ & $8.58 \pm 0.974$ & $\mathrm{H}$ \\
\hline 46 & & Romosozumab therapy should last for 12 months & $2 \mathrm{a}$ & $8.59 \pm 0.829$ & $\mathrm{H}$ \\
\hline 47 & Monitoring & BMD testing can be used to monitor response to therapy & $2 b$ & $8.13 \pm 1.262$ & $\mathrm{H}$ \\
\hline 48 & & FRAX can be used to monitor response to therapy & 5 & $8.66 \pm 0.702$ & $\mathrm{H}$ \\
\hline
\end{tabular}


Table 2 Breakdown of statements of recommendations, its individual rank, and level of agreement (Continued)

\begin{tabular}{|c|c|c|c|c|c|}
\hline No. & Standard & Statement & LE & Mean rate \pm SD & $\begin{array}{l}\text { Level of } \\
\text { agreement }\end{array}$ \\
\hline 49 & & $\begin{array}{l}\text { Check adherence within } 3 \text { months and yearly thereafter, } \\
\text { including tolerability, new cautions and } \\
\text { contraindications, calcium/vitamin D intake, change in } \\
\text { fracture, and fall risks }\end{array}$ & $2 b$ & $8.67 \pm 0.702$ & $\mathrm{H}$ \\
\hline 50 & & $\begin{array}{l}\text { In the case of oral bisphosphonate or denosumab, } \\
\text { repeat BMD measurement should be carried out after } \\
\text { initial } 2 \text { years of osteoporosis therapy to assess the } \\
\text { response to treatment and then at } 5 \text { years when the } \\
\text { patient completes the treatment course. In the case of } \\
\text { IV zoledronate, repeat DXA scan should be carried out } \\
\text { after } 3 \text { years of therapy }\end{array}$ & $2 a$ & $8.83 \pm 0.565$ & $\mathrm{H}$ \\
\hline 51 & & $\begin{array}{l}\text { At the repeat BMD assessment carried out } 2 \text { years after } \\
\text { starting osteoporosis therapy, good response to } \\
\text { treatment is identified if there is increase (increase of } \\
\text { the BMD above the precision error) or stability of BMD } \\
\text { without the occurrence of low trauma fracture. }\end{array}$ & 1 & $8.66 \pm 0.637$ & $\mathrm{H}$ \\
\hline 52 & & $\begin{array}{l}\text { Treatment failure is considered when the BMD falls } \\
\text { significantly from baseline (by more than the precision } \\
\text { error) or if further fractures took place despite an } \\
\text { adequate trial and adherence to drug treatment. } \\
\text { However, it is important to realise that even the best } \\
\text { treatments will only decrease the fracture rate }\end{array}$ & $2 a$ & $7.96 \pm 1.398$ & $\mathrm{H}$ \\
\hline 53 & & $\begin{array}{l}\text { Patients should continue to receive the same treatment } \\
\text { for osteoporosis during the initial } 2 \text { years of treatment } \\
\text { even if they experience a fragility fracture }\end{array}$ & $2 \mathrm{a}$ & $8.63 \pm 0.969$ & $\mathrm{H}$ \\
\hline 54 & & $\begin{array}{l}\text { If a patient remains at high fracture risk or develop a } \\
\text { fragility fracture after } 2 \text { years of being on the same } \\
\text { treatment, in spite of good adherence to therapy and } \\
\text { after exclusion of secondary causes, then consider } \\
\text { switching to another therapy }\end{array}$ & $2 \mathrm{a}$ & $8.79 \pm 0.588$ & $\mathrm{H}$ \\
\hline 55 & & $\begin{array}{l}\text { If a patient has a new fracture, during their treatment } \\
\text { break, they should be reassessed immediately }\end{array}$ & $2 a$ & $8.83 \pm 0.381$ & $\mathrm{H}$ \\
\hline 56 & & $\begin{array}{l}\text { During treatment, all patients should be encouraged to } \\
\text { maintain good oral hygiene, receive routine dental } \\
\text { check-ups, and report any oral symptoms such as den- } \\
\text { tal mobility, pain, or swelling }\end{array}$ & $2 b$ & $8.96 \pm 0.204$ & $\mathrm{H}$ \\
\hline 57 & & $\begin{array}{l}\text { During treatment, patients should be advised to report } \\
\text { any thigh, hip, or groin pain and any patient presenting } \\
\text { with such symptoms should be evaluated for an } \\
\text { atypical femur fracture }\end{array}$ & $2 b$ & $8.79 \pm 0.588$ & $\mathrm{H}$ \\
\hline 58 & & $\begin{array}{l}\text { During treatment with bisphosphonate or denosumab, } \\
\text { patients should be advised to report jaw pain, swelling, } \\
\text { or gum infections; development of exposed bone in } \\
\text { the mouth along either the top or bottom jaws; } \\
\text { loosening of teeth; poor healing of the gums especially } \\
\text { after dental work, or numbness or a feeling of } \\
\text { heaviness in the jaw }\end{array}$ & $2 b$ & $8.75 \pm 0.532$ & $\mathrm{H}$ \\
\hline 59 & Drug Holiday & $\begin{array}{l}\text { Drug holiday can be considered after completing } 5 \\
\text { years of oral bisphosphonate/denosumab therapy or } 3 \\
\text { years of zoledronate IV therapy if the target of } \\
\text { treatment has been achieved }\end{array}$ & $2 \mathrm{a}$ & $8.46 \pm 0.78$ & $\mathrm{H}$ \\
\hline 60 & & $\begin{array}{l}\text { Patients with low to moderate fracture risk: consider } \\
\text { giving bisphosphonate then stopping for a drug holiday }\end{array}$ & $2 \mathrm{a}$ & $8.67 \pm 0.702$ & $\mathrm{H}$ \\
\hline 61 & & Once a holiday has begun, fracture risk and BMD & $2 \mathrm{a}$ & $8.79 \pm 0.589$ & $\mathrm{H}$ \\
\hline
\end{tabular}
should be re-evaluated every 1 to 3 years after discontinuation. A significant drop in BMD (by more than a precision error) or increase in the fracture risk may lead to re-initiation of osteoporosis therapy, depending on the individual's fracture risk before the 5-year maximum holiday is completed 
Table 2 Breakdown of statements of recommendations, its individual rank, and level of agreement (Continued)

\begin{tabular}{|c|c|c|c|c|c|}
\hline No. & Standard & Statement & LE & Mean rate \pm SD & $\begin{array}{l}\text { Level of } \\
\text { agreement }\end{array}$ \\
\hline 62 & & $\begin{array}{l}\text { - Patients on corticosteroids ( } \geq 7.5 \mathrm{mg} / \text { day) or patients } \\
\text { who have had a vertebral fracture should not usually } \\
\text { be considered for a treatment break } \\
\text { - Women and men age } \geq 70 \text { years, with a previous } \\
\text { fragility fracture, or taking high doses of } \\
\text { glucocorticoids ( } \geq 7.5 \mathrm{mg} / \text { day prednisolone) should } \\
\text { be considered for bone protective therapy, after BMD } \\
\text { baseline assessment } \\
\text { - In other individuals, fracture probability should be } \\
\text { estimated using FRAX with adjustment for } \\
\text { glucocorticoid dose. Baseline BMD assessment is } \\
\text { advised. } \\
\text { - Bone-protective treatment should be started at the } \\
\text { onset of glucocorticoid therapy in individuals at mod- } \\
\text { erate/high risk of fracture } \\
\text { - Alendronate and risedronate are first-line treatment } \\
\text { options. Where these are contraindicated or not toler- } \\
\text { ated, zoledronic acid, teriparatide, or denosumab (in } \\
\text { order) are alternative options } \\
\text { - Bone-protective therapy may be appropriate in some } \\
\text { premenopausal women and younger men, particularly } \\
\text { in individuals with a previous history of fracture or re- } \\
\text { ceiving high doses of glucocorticoids } \\
\text { - For women in the childbearing period: the first-line } \\
\text { therapy is an oral bisphosphonate; second-line ther- } \\
\text { apy is a parathyroid hormone }\end{array}$ & $2 a$ & $8.5+0.781$ & $\mathrm{H}$ \\
\hline 63 & Osteoporosis in men & $\begin{array}{l}\text { - Osteoporosis screening in men should be carried out } \\
\text { in the age of } 70 \text { years or older } \\
\text { - Men at age less than } 70 \text { years old can be assessed for } \\
\text { osteoporosis if they develop risk factors } \\
\text { - Men with osteopaenia ( } T \text { score from - } 1 \text { to - 2.5) } \\
\text { who have moderate risk of fracture FRAX fracture risk } \\
\text { probability } 1-3 \% \text { at the hip and } 10-20 \% \text { at spine may } \\
\text { be good candidates for prophylactic zoledronic acid } \\
\text { every } 18 \text { months for } 4 \text { infusions } \\
\text { - For the purposes of FRAX calculations, the BMD T } \\
\text { scores in men are calculated based on the female } \\
\text { reference database } \\
\text { - Secondary causes of osteoporosis are commonly } \\
\text { found amongst men, so this population requires } \\
\text { thorough investigation } \\
\text { - Intervention thresholds for men are similar to those } \\
\text { recommended for women } \\
\text { - All men starting on androgen deprivation therapy } \\
\text { should have their fracture risk assessed } \\
\text { - Consider referring men with osteoporosis to specialist } \\
\text { centres, particularly younger men or those with } \\
\text { severe disease } \\
\text { - Men are assessed and treated following the same } \\
\text { management protocol suggested above for } \\
\text { postmenopausal women, excluding the HRT }\end{array}$ & $2 a$ & $8.66 \pm 0.637$ & $\mathrm{H}$ \\
\hline 64 & $\begin{array}{l}\text { Post-fracture care and } \\
\text { Fracture Liaison service }\end{array}$ & $\begin{array}{l}\text { Fracture Liaison Services (FLS) should be provided for } \\
\text { all patients sustaining a fragility fracture: } \\
\text { - Ensure treatment initiation within } 16 \text { weeks of fracture } \\
\text { - FLS should be patient-centred and integrated be- } \\
\text { tween orthopaedic surgery, orthogeriatrics, rheumatol- } \\
\text { ogy, and osteoporosis centres of care. Physicians } \\
\text { should follow up patients at } 4 \text { and } 12 \text { months to re- } \\
\text { view the use of medications that increase the risk of } \\
\text { falls and/or fracture, to ensure co-prescription of cal- } \\
\text { cium and vitamin D with bone protective interven- } \\
\text { tions and to monitor adherence to therapy }\end{array}$ & $2 a$ & $8.67 \pm 0.868$ & $\mathrm{H}$ \\
\hline
\end{tabular}


Table 3 The anti-fracture efficacy of the approved therapies for postmenopausal women with osteoporosis when given with calcium and vitamin D

\begin{tabular}{llll}
\hline Intervention & Vertebral fracture & Non-vertebral fracture & Hip fracture \\
\hline Alendronate & A & A & A \\
Ibandronate & A & $A^{*}$ & NAE* \\
Risedronate & A & A & A \\
Zoledronic acid & A & A & A \\
Denosumab & A & A & A \\
HRT & A & A & A \\
Raloxifene & A & NAE & NAE \\
Teriparatide & A & A & NAE \\
Romosozumab & A & A & A \\
\hline
\end{tabular}

A grade A recommendation, NAE not adequately evaluated, $H R T$ hormone replacement therapy

*In subsets of patients only (post hoc analysis)

volume of comments (excluding minor editing suggestions) was highest for the intervention thresholds for osteoporosis-specific therapies, treat-to-target criteria, the need to consider individual patient characteristics, pharmacological management, duration of therapy, monitoring, and drug holiday. Diversity of opinion was greatest for the item on using bone markers for monitoring of the patient's condition. Three statements were retired, one on the use of bone markers for monitoring of the osteoporosis therapy, and 2 statements for similarities to other statements.

\section{Round 2}

The response rate for round 2 was 100\% (24/24). Agreement with the recommendations (rank 7-9) ranged from 83.4 to $100 \%$. One statement was retired for similarity with another statement. Consensus was reached (i.e. $\geq$ $75 \%$ of respondents strongly agreed or agreed) on the wording of all 16 clinical standards. Table 2 also shows the level of evidence assigned to each statement, in accordance with the Oxford Centre for Evidence-Based Medicine (CEBM) criteria as well as mean \pm standard deviation and level of agreement. Agreement was unanimous ( $>80 \%$ agreement) for the wording of the statements.

\section{Application of the standards framework to clinical practice guidelines}

Clinicians need information that is clear and readily accessible. Osteoporosis guidelines should clearly articulate which individuals should be identified for assessment, the investigations that should be offered, appropriate indications for treatment, the pharmacological treatments and other interventions that should be offered to specific patient groups, information on lifestyle changes that should be provided to patients, how the levels of healthcare systems should be integrated to ensure seamless care, and how the quality of osteoporosis healthcare services should be monitored and improved. Figure 1 shows an algorithm for the management of postmenopausal osteoporosis.

\section{Discussion}

This work was carried out to formulate an updated clinical practice guideline for the pharmacological management of osteoporosis in postmenopausal women and men in Egypt, based on an expert consensus on a treatto-target (T2T) strategy in osteoporosis. There were guidelines for the diagnosis and management of osteoporosis amongst Egyptians [23]; however, this was based on the review of the literature and presented as an abstract and not published in a full manuscript. To our

Table 4 Approved interventions for glucocorticoid-induced osteoporosis and its effect on BMD and fracture risk

\begin{tabular}{lllll}
\hline Intervention & Spine BMD & Hip BMD & Vertebral fracture & Non-vertebral fracture \\
\hline Alendronate & $A$ & $A$ & $B^{b}$ & NAE \\
Risedronate & $A$ & $A$ & $A^{b}$ & NAE \\
Teriparatide & $A^{a}$ & $A^{a}, b$ & $N A E$ \\
Zoledronic acid & $A^{a}$ & $A^{a}$ & NAE & NAE \\
Denosumab & $A^{a}$ & $A^{a}$ & NAE & NAE \\
\hline
\end{tabular}

$A$ grade $A$ recommendation, $B$ grade $B$ recommendation, NAE not adequately evaluated

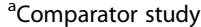

${ }^{\mathrm{b}}$ Not a primary endpoint 


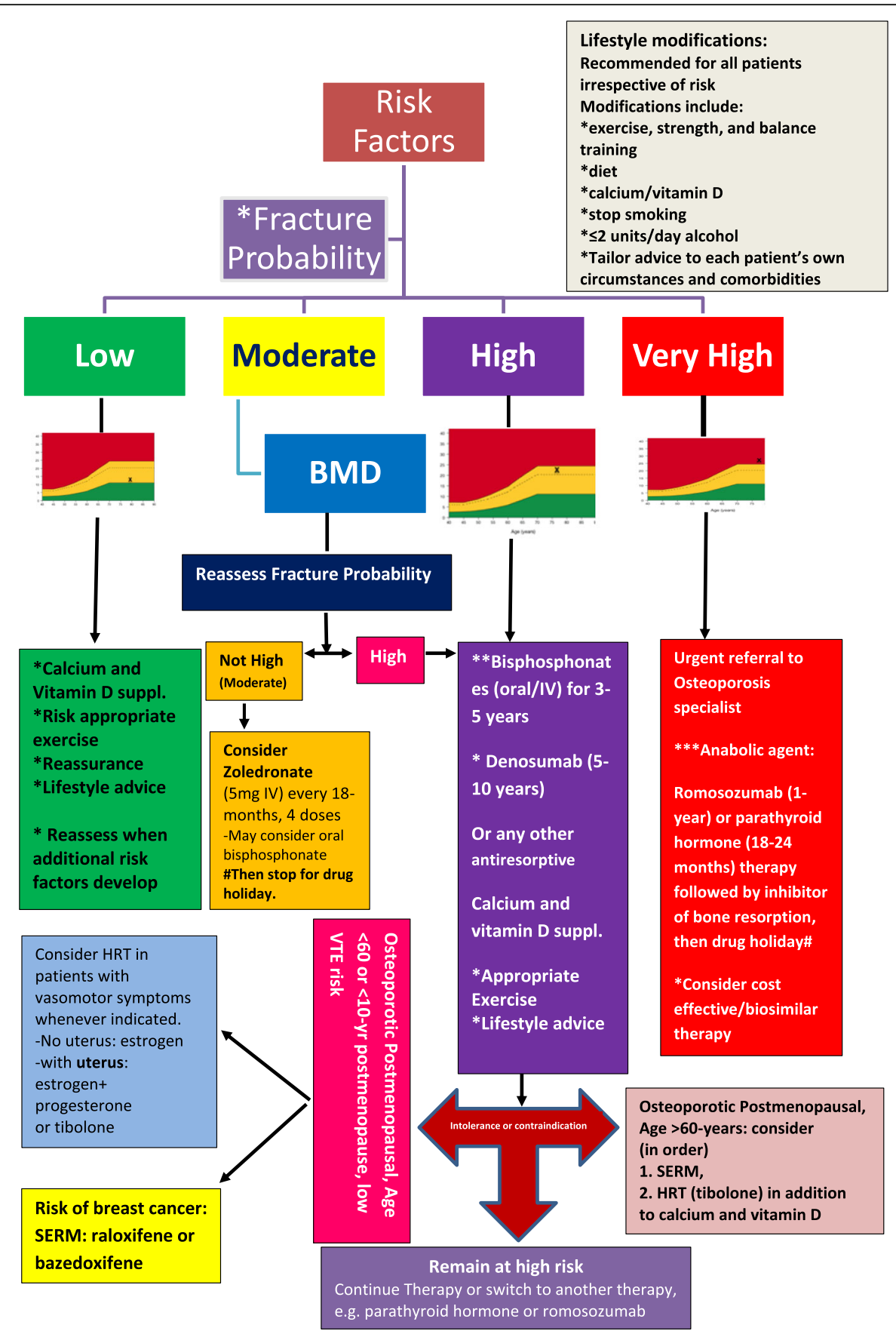

Monitor Therapy: Clinic visit within 3-months then yearly. BMD at 2 and 5-years from starting therapy 0

Fig. 1 (See legend on next page.) 
(See figure on previous page.)

Fig. 1 Figure 1 provides an algorithm summarising the group's consensus recommendations for the management of patients categorised according to their fracture risk. Case finding and treatment pathways according to the categorisation of fracture risk: updated algorithm for management of postmenopausal osteoporosis. The determination of fracture risk was carried out based on fracture risk score calculation (e.g. FRAX) and the measurement of lumbar spine and hip BMD. *Stratification of osteoporotic fracture risk can be based on (I) NOGG (UK) as shown in the figures. The intervention threshold is set at a risk equivalent to that associated with a prior fracture. Two intervention thresholds are identified based on FRAX calculation based on BMD assessment. The treatment modality is suggested based on whether the individual either exceed the intervention threshold or lie below it. Alternatively, (II) using FRAX score alone, the fracture risks can be defined as follows: (1) low risk includes no prior hip or spine fractures, a BMD T score at the hip and spine both above - 1.0, a 10-year hip fracture risk < 1\%, and 10-year risk of major osteoporotic fractures < 10\%; (2) moderate risk includes no prior hip or spine fractures, a BMD T score at the hip and spine both above 2.5, and 10-year hip fracture risk < 3\% or risk of major osteoporotic fractures < 20\%; (3) high risk includes a prior spine or hip fracture, or a BMD $T$ score at the hip or spine of -2.5 or below, or 10 -year hip fracture risk $\geq 3 \%$, or risk of major osteoporotic fracture risk $\geq 20 \%$; and (4) very high risk includes multiple spine fractures and a BMD T score at the hip or spine of -2.5 or below. ${ }^{* *}$ Continue treatment up to 3 years (IV zoledronate) or 5 years (oral bisphosphonate/denosumab), reassess fracture risk: (1) if low or low-moderate risk: consider drug holiday. Reassess fracture risk every 1-3 years; if bone loss, fracture occurs, or the patient becomes high risk consider restarting therapy. (2) If high risk continues therapy after checking for adherence or switch to another therapy. ${ }^{* *}$ After completion of the anabolic therapy course, consider giving bisphosphonate, then stopping for a drug holiday. ${ }^{\diamond}$ Patient who remains at high fracture risk or develop a fragility fracture after 2 years of being on the same treatment, in spite of good adherence to therapy and after exclusion of secondary causes, then consider switching to another therapy. "Drug holiday: patients should be assessed at 3 years (zoledronate) and 5 years (oral bisphosphonate/denosumab). Patients who achieve the expected treatment target can be offered a drug holiday. Reassess fracture risk every 1-3 years. If bone loss, fracture occurs, or patients become at high risk, consider restarting therapy

knowledge, this is the first expert consensus regarding the applicability of a T2T strategy for osteoporosis in clinical practice in Egypt. The study results reflect data not only from pivotal published treatment recommendations but also from post-authorisation studies and, above all, the expert opinion.

The prevalence of osteoporosis in Egypt has been rated at $28.4 \%$ in women and $21.9 \%$ in men, whereas $53.9 \%$ of women and $26 \%$ of men had osteopaenia [24]. In rural areas of Upper Egypt, the prevalence of osteoporosis in postmenopausal women was even higher reaching up to $47.8 \%$. Such high prevalence highlights the magnitude of the problem in terms of public health and the importance of having up-to-date guidelines for the management of osteoporosis in Egypt [25].

The treat-to-target approach has been recently suggested as a useful strategy to osteoporosis management $[26,27]$. The policy of treating to a prespecified target in medical practice involves the definition of a level of a chosen disease gold standard (a biomarker) that is associated with optimal protection against the detrimental effects of the specific disease. The new concepts of very high fracture risk and the development of new assessment and intervention thresholds [28], provided a platform based on which of these guidelines have been developed for national use to characterise fracture risk and direct interventions. The very high fracture risk and the consequent further utility loss immediately after a subsequent fracture (imminent risk) suggests that preventive treatment given as soon as possible after fracture would avoid a higher number of new fractures and reduce the attendant morbidity, compared with the treatment given later. This data provided the rationale for these guidelines recommending very early intervention with osteoanabolic agents, immediately after a sentinel fracture. These agents offer the fastest effect on fracture reduction compared to the antiresorptive therapies [2933]. Whilst these treatment recommendations have the potential to revolutionise treatment strategies, particularly in individuals at very high fracture risk, they are in agreement with the most recent published treatment recommendations [34, 35].

The Delphi technique has proven to be a reliable measurement instrument in developing new concepts and setting the direction of future-orientated research [36]. The technique seeks the opinion of a group of experts in order to assess the extent of agreement and to resolve disagreement on an issue [37]. When the experts were asked about the possibility of implementing a welldefined objective in osteoporosis, there was a wide consensus. Almost all contributors agreed on the opportunity of implementing treat-to-target strategy in clinical practice of osteoporosis. In Delphi methodology, consensus usually arises when agreement or disagreement ranges from 50 to $80 \%$ [38]. In our work, the agreement ranged between 83.4 and $100 \%$, indicating a strong trend amongst the Egyptian health care professionals to have a T2T approach for osteoporosis management. These findings are in agreement with the results of the Spanish consensus on osteoporosis management [39] which revealed similar agreement on the treat to target policy.

The guidelines endorsed the concept that the choice of pharmacological osteoporosis therapy varies according to the fracture risk level and that the future fracture risk is a continuum from low risk through high risk to very high risk rather than discrete risk categories. In cases where the patient's score is close to the threshold between two risk levels, individual patient factors should 
be considered to help in deciding the appropriate management options. Therefore, to meet the treat-to-target requirements, an individualised treatment decision should be made for every patient tailored to the patients' medical history and their fracture risk level. These recommendations are in agreement with those published recently by the European Endocrine of Society [34] as well as those published in the UK consensus management of patients at low, high, and very high risk of osteoporotic fracture [35].

Good prescribing practice means that osteoporosis management should be commenced and monitored by a health care professional with clinical experience with the condition, the medication used, and any possible adverse effects. Specialists can help with treatment decisions particularly for high-risk patients or those patients who had previously anti-resorptive medications. This aims to streamline the osteoporosis service provided to the patients in Egypt and ensure that osteoporosis therapy is determined or escalated according to the patient's risk factors and fracture risk within an approved framework. This work included healthcare professionals from all the universities as well as Ministry of Health hospitals in Egypt, so it is expected to be implemented across the whole country.

Translation of the guideline into easy to use, practical algorithms is vital and highly required to facilitate the identification and management in the day to day standard clinical practice. The algorithm developed in this study enabled the incorporation of several recent developments into the patient management protocols. These could significantly positively impact on the treatment outcome and pave the way to strategies. Broadly, the algorithm is in agreement with that suggested recently by the European Society of Endocrinology particularly concerning the treatment of patients at very high risk of fracture with initial osteoanabolic therapies [34], as well as the American Society for Bone and Mineral Research (ASBMR) Task Force suggestion that those at low to moderate fracture risk can initiate a bisphosphonate holiday, whereas those at high risk should continue the bisphosphonate or switch to another therapy [40]. Also, it is in agreement with the outcomes of the FLEX trial which was concerned with fracture prediction after discontinuation of $4-5$ years of alendronate [41] and HORIZON [42] trials for identifying candidates for a drug holiday, based on vertebral fracture status and femoral neck BMD at the time of potential discontinuation.

There are no guidelines or recommendations on the appropriate sample size for expert-consensus Delphi studies or a standardised definition of a small or large sample size. Earlier published data [43] reported that depending on the purpose of the study, the complexity, and the expertise required, the panel may be large or small and local, state, national, or international. Group size theory varies, but some general rules-of-thumb indicate 15-30 people for a homogeneous population, that is experts coming from the same discipline and 5-10 people for a heterogeneous population. The consensus panel included in this study included 24 experts with a participation percentage of $96 \%$ in both rounds. The study carried out to assess the relevant risk predictors for the occurrence of osteoporotic fractures in specific clinical subgroups included 11 experts in the Delphi survey [44]. Similarly, the study carried out to develop a fracture risk clinical assessment protocol for long-term care included 24 experts [45]. On the other hand, in the Spanish consensus on treat-to-target for osteoporosis study [39], 165 experts from all over Spain were invited to participate by e-mail in the Delphi survey. Of these, 112 answered the first-round questionnaire $(67.88 \%$ of the experts contacted) and 106 completed the secondround questionnaire.

The main strengths of the study are related to the diversity as well as the expertise of the participants, the high levels of consensus achieved, and the agreement with the most recently published osteoporosis treatment recommendations. The main limitation is related to the scope of the study, which was carried out in Egypt, and the outcomes may not be applicable to other countries. It would be interesting to do a similar study using the Delphi methodology with international experts and to evaluate and compare the outcomes.

\section{Conclusion}

This was a wide and representative panel of experts who established consensus regarding the management of osteoporosis in Egypt. This included case identification, who to treat, case stratification, diagnosis, therapeutic objectives, patient monitoring, treatment duration, and the facility of having drug holiday. It also expanded to give guidance for the management of osteoporosis in men and the potential role of fracture liaison service in standard practice. Prophylactic measures, early diagnosis, and a proper therapeutic approach were vital for bone health improvement.

\author{
Abbreviation \\ T2T: Treat-to-target \\ Acknowledgements \\ No acknowledgement.

\section{Authors' contributions} \\ All authors have read and approved the manuscript. YEM Conceptualisation, \\ methodology, investigation, writing - original draft. MHAZ Conceptualisation, \\ methodology, investigation, online voting platform, collection of data and \\ analysis, critical review of the manuscript. MEG Conceptualisation, \\ methodology, investigation, writing - review and editing. MMHEN \\ Developing the clinical questions, statements of recommendations and \\ voting, critical review of the manuscript. NF Developing the clinical \\ questions, statements of recommendations and voting, critical review of the
}


manuscript. WH Developing the clinical questions, statements of recommendations and voting, critical review of the manuscript. M E Developing the clinical questions, statements of recommendations and voting, critical review of the manuscript. HK Developing the clinical questions, statements of recommendations and voting, critical review of the manuscript. NM Developing the clinical questions, statements of recommendations and voting, critical review of the manuscript. MM Developing the clinical questions, statements of recommendations and voting, critical review of the manuscript. SIN Developing the clinical questions, statements of recommendations and voting, critical review of the manuscript. SG Developing the clinical questions, statements of recommendations and voting, critical review of the manuscript. HGS Developing the clinical questions, statements of recommendations and voting, critical review of the manuscript. RMG Developing the clinical questions, statements of recommendations and voting, critical review of the manuscript. SAHT Developing the clinical questions, statements of recommendations and voting, critical review of the manuscript. SSM Developing the clinical questions, statements of recommendations and voting, critical review of the manuscript. BMM Developing the clinical questions, statements of recommendations and voting, critical review of the manuscript. HMA Developing the clinical questions, statements of recommendations and voting, critical review of the manuscript. GE Developing the clinical questions, statements of recommendations and voting, critical review of the manuscript. NAF Developing the clinical questions, statements of recommendations and voting, critical review of the manuscript. SSG Developing the clinical questions, statements of recommendations and voting, critical review of the manuscript. YA Developing the clinical questions, statements of recommendations and voting, critical review of the manuscript. MMEl Developing the clinical questions, statements of recommendations and voting, critical review of the manuscript. OF Developing the clinical questions, statements of recommendations and voting, critical review of the manuscript. NAG Developing the clinical questions, statements of recommendations and voting, critical review of the manuscript

\section{Funding}

Nothing to declare.

\section{Availability of data and materials}

It will be available on request.

\section{Ethics approval and consent to participate}

The need for ethics approval was waived according to national regulations (The Egyptian national Ethical Committee).

\section{Consent for publication}

Not applicable.

\section{Competing interests}

Two of the co-authors are the Editors-in-Chief for the Egyptian Rheumatology and Rehabilitation journal.

\section{Author details}

'Rheumatology and Rehabilitation, Ain Shams University, Cairo, Egypt. 'King's College London, London, UK. ${ }^{3}$ Rheumatology and Rehabilitation, Tanta University, Tanta, Egypt. ${ }^{4}$ Community and Public Health, Ain Shams University, Cairo, Egypt. ${ }^{5}$ Rheumatology, Physical Medicine and Rehabilitation, Ain Shams University, Cairo, Egypt. ${ }^{6}$ Rheumatology and Rehabilitation, Assiut University, Assiut, Egypt. ${ }^{7}$ Geriatrics and Gerontology, Ain Shams University, Cairo, Egypt. ${ }^{8}$ Rheumatology and Rehabilitation, Benha University, Benha, Egypt. ${ }^{9}$ Rheumatology and Rehabilitation Department, Cairo University, Cairo, Egypt. ${ }^{10}$ Internal Medicine and Rheumatology, Alexandria University Hospitals, Alexandria University, Alexandria, Egypt. ${ }^{11}$ Rheumatology and Rehabilitation, Zagazig University, Sharkeyya, Egypt. ${ }^{12}$ Rheumatology and Rehabilitation, Faculty of Medicine, Suez Canal University, Ismailia, Egypt. ${ }^{13}$ Rheumatology and Rehabilitation Department, Minia University, Minia, Egypt. ${ }^{14}$ Rheumatology and Rehabilitation, Al-Azhar University, Cairo, Egypt.

${ }^{15}$ Rheumatology and Rehabilitation, Fayoum University, Fayoum, Egypt.

${ }^{16}$ Rheumatology, Physical Medicine and Rehabilitation, Benha University, Benha, Egypt. ${ }^{17}$ Rheumatology and Rehabilitation, Mansoura University, Mansoura, Egypt. ${ }^{18}$ Rheumatologist, Rheumatology and Immunology, Health
Insurance, Ministry of Health, Cairo, Egypt. ${ }^{19}$ Orthopedic Surgery, Department of Orthopaedic and Trauma Surgery, Faculty of Medicine, Assiut University Hospitals, Assiut, Egypt.

Received: 3 December 2020 Accepted: 23 December 2020

Published online: 28 January 2021

\section{References}

1. National Osteoporosis Foundation. About NOF. Available at: www.nof.org/ about-us/about-nof/. Accessed Nov 2020

2. Cooper C (1997) The crippling consequences of fractures and their impact on quality of life. Am J Med 103(2A):12S-17S

3. Hajcsar EE, Hawker G, Bogoch ER (2000) Investigation and treatment of osteoporosis in patients with fragility fractures. CMAJ 163(7):819-822

4. Hopkins RB, Pullenayegum E, Goeree R, Adachi JD, Papaioannou A, Leslie WD, Tarride JE, Thabane $L$ (2012) Estimation of the lifetime risk of hip fracture for women and men in Canada. Osteoporos Int 23(3):921-927

5. Ioannidis G, Papaioannou A, Hopman WM, Akhtar-Danesh N, Anastassiades T, Pickard L, Kennedy CC, Prior JC, Olszynski WP, Davison KS, Goltzman D, Thabane L, Gafni A, Papadimitropoulos EA, Brown JP, Josse RG, Hanley DA, Adachi JD (2009) Relation between fractures and mortality: results from the Canadian Multicentre Osteoporosis Study. CMAJ 181(5):265-271

6. Gehlbach S, Saag KG, Adachi JD, Hooven FH, Flahive J, Boonen S, Chapurlat RD, Compston JE, Cooper C, Diez-Perez A, Greenspan SL, AZ LC, Netelenbos JC, Pfeilschifter J, Rossini M, Roux C, Sambrook PN, Silverman S, Siris ES, Watts NB, Lindsay R (2012) Previous fractures at multiple sites increase the risk for subsequent fractures: the Global Longitudinal Study of Osteoporosis in Women. J Bone Miner Res 27(3):645-653

7. Johansson H, Siggeirsdottir K, Harvey NC, Oden A, Gudnason V, McCloskey E, Sigurdsson G, Kanis JA (2017) Imminent risk of fracture after fracture. Osteoporos Int 28:775-780

8. Borgström F, Karlsson L, Ortsäter G et al (2020) Fragility fractures in Europe: burden, management and opportunities. Arch Osteoporos 15:59

9. Maalouf G, Gannagé-Yared MH, Ezzedine J, Larijani B, Badawi S, Rached A, Zakroui L, Masri B, Azar E, Saba E, Nammari R, Adib G, Abou Samra H, Alrawi Z, Salman S, El Muntasser K, Tarseen R, El Kharousi W, Al-Lamki M, Alothman AN, Almarzook N, El Dessouki M, Sulaimani R, Saleh J, Suhaili AR, Khan A, Delmas P, Seeman E (2007) Middle East and North Africa consensus on osteoporosis. J Musculoskelet Neuronal Interact 7(2):131-143

10. Taha M. Prevalence of osteoporosis in Middle East systemic literature review. In: Proceedings of the 10th ECOO: 2011 April 14-16. Cairo: AO Foundation. Available online at URL: <http://www.scribd.com/doc/53103 901/Osteopoorosis-Cairo-April-2011-v1> Accessed Nov 2020.

11. El-Tawab SS, Saba EKA, Elweshahi HMT, Ashry MH (2016) Knowledge of osteoporosis among women in Alexandria (Egypt): a community based survey. Egypt Rheumatol 38(3):225-231

12. Salem D, Tattawi S, Ebrashi H (2000) Evaluation of osteoporosis among males and females in clinical practices bone densitometry. Med J Cairo Univ 68:89-92

13. Farouk O, Mahran DG, Said HG et al (2017) Osteoporosis among hospitalized patients with proximal femoral fractures in Assiut University Trauma Unit. Egypt Arch Osteoporos 12(1):12

14. Barrett-Connor E, Wade SW, Do TP, Satram-Hoang S, Stewart R, Gao G et al (2012) Treatment satisfaction and persistence among postmenopausal women on osteoporosis medication: 12-month results from POSSIBLE US ${ }^{\mathrm{TM}}$. Osteoporos Int 23:733-741

15. Inzucchi SE, Bergenstal RM, Buse JB, Diamant M, Ferrannini E, Nauck M, Peters AL, Tsapas A, Wender R, Matthews DR (2015) Management of hyperglycemia in type 2 diabetes, 2015: a patient centered approach: update to a position statement of the American Diabetes Association and the European Association for the Study of Diabetes. Diab Care 38(1):140149

16. McCloskey E (2015) Can we treat to target in osteoporosis? Int J Clin Rheumatol 10(1):1-4

17. Lewiecki EM (2017) Osteoporosis: treat-to-target. Curr Osteoporos Rep 15(2): 103-109

18. Hsu CC, Sandford BA (2007) The Delphi technique: making sense of consensus. Practical assess. Res Eval 12:1-8

19. Diamond IR, Grant RC, Feldman BM, Pencharz PB, Ling SC, Moore AM, Wales PW (2014) Defining consensus: a systematic review recommends 
methodologic criteria for reporting of Delphi studies. J Clin Epidemiol 67(4): 401-409

20. Von der Gracht H (2012) Consensus measurement in Delphi studies: review and implications for future quality assurance. Technol Forecast Soc 79(8): 1525-1536

21. Hansen MP, BjerrumL G-HB, Jarbol DE (2010) Quality indicators for diagnosis and treatment of respiratory tract infections in general practice: a modified Delphi study. Scand J Public Health 28:4-11

22. Lai L, Flower A, Moore M, Lewith G (2015) Developing clinical practice guidelines for Chinese herbal treatment of polycystic ovary syndrome: a mixed-methods modified Delphi study complement. Ther Med 23(3):430438

23. El-Badawy S, Abdel-Azeem H, El-Garf A et al (2012) Egyptian guidelines for the diagnosis and management of osteoporosis. (Abstract). Egyptian Society of Osteoporosis and Geriatrics (ESOG), Cairo.

24. Taha M. Prevalence of osteoporosis in Middle East systemic literature review, 10th ECOO, April 2011.

25. Gheita T, Hammam N (2018) Epidemiology and awareness of osteoporosis: a viewpoint from the Middle East and North Africa. Int J Clin Rheumatol 13(3):134-147

26. Lewiecki EM, Cummings SR, Cosman F (2013) Treat-to-target for osteoporosis: is now the time? J Clin Endocrinol Metab 98(3):946-953

27. Cummings SR, Cosman F, Eastell R, Reid IR, Mehta M, Lewiecki EM (2013) Goal-directed treatment of osteoporosis. J Bone Miner Res 28(3):433-438

28. Kanis JA, Harvey NC, McCloskey E et al (2020) Algorithm for the management of patients at low, high and very high risk of osteoporotic fractures. Osteoporos Int 31:1-12

29. Kendler DL, Marin F, Zerbini CAF, Russo LA, Greenspan SL, Zikan V, Bagur A, Malouf-Sierra J, Lakatos P, Fahrleitner Pammer A, Lespessailles E, Minisola S, Body JJ, Geusens P, Möricke R, López-Romero P (2018) Effects of teriparatide and risedronate on new fractures in post-menopausal women with severe osteoporosis (VERO): a multicentre, double-blind, doubledummy, randomised controlled trial. Lancet 391(10117):230-240

30. Saag KG, Petersen J, Brandi ML, Karaplis AC, Lorentzon M, Thomas T, Maddox J, Fan M, Meisner PD, Grauer A (2017) Romosozumab or alendronate for fracture prevention in women with osteoporosis. N Engl J Med 377:1417-1427

31. Barrionuevo P, Kapoor E, Asi N, Alahdab F, Mohammed K, Benkhadra K, Almasri J, Farah W, Sarigianni M, Muthusamy K, Al Nofal A, Haydour Q, Wang Z, Murad MH (2019) Efficacy of pharmacological therapies for the prevention of fractures in postmenopausal women: a network metaanalysis. J Clin Endocrinol Metab 104:1623-1630

32. Lou S, Lv H, Yin P, Li Z, Tang P, Wang Y (2019) Combination therapy with parathyroid hormone analogs and antiresorptive agents for osteoporosis: a systematic review and meta-analysis of randomized controlled trials. Osteoporos Int 30:59-70

33. Díez-Pérez A, Marin F, Eriksen EF, Kendler DL, Krege JH, Delgado-Rodríguez M (2019) Effects of teriparatide on hip and upper limb fractures in patients with osteoporosis: a systematic review and meta-analysis. Bone 120:1-8

34. Eastell R, Rosen CJ, Black DM, Cheung AM, Murad MH, Shoback D (2019) Pharmacological management of osteoporosis in postmenopausal women: an Endocrine Society Clinical Practice Guideline. J Clin Endocrinol Metab 104(5):1595-1622

35. UK consensus guideline on the management of patients at low, high, and very high risk of osteoporotic fracture. Cyrus Cooper,1 Kassim Javaid,2 Mary Elliott,3 David Stephens,4 Nuttan Tanna. www.Guidelines.co.uk 2020 [https:// www.quidelines.co.uk/musculoskeletal-and-joints-/osteoporotic-fractureguideline/455546.article ] accessed on 15th November 2020.

36. Rowe G, Wright G (1999) The Delphi technique as a forecasting tool: issues and analysis. Int J Forecast. 15:353-375

37. Jones J, Hunter D (1995) Consensus methods for medical and health services research. BMJ. 311:376-380

38. Rayens MK, Hahn EJ (2000) Building consensus using the policy Delphi method. Policy Polit Nurs Pract 1(4):308-315

39. Nogués $X$, Nolla JM, Casado E, Jódar E, Muñoz-Torres M, Quesada-Gómez JM, Canals L, Balcells M, Lizán L (2018) Spanish consensus on treat to target for osteoporosis. Osteoporos Int 29(2):489-499

40. Adler RA, El-Hajj Fuleihan G, Bauer DC, Camacho PM, Clarke BL, Clines GA, Compston JE, Drake MT, Edwards BJ, Favus MJ, Greenspan SL, McKinney R Jr, Pignolo RJ, Sellmeyer DE (2016) Managing osteoporosis in patients on long-term bisphosphonate treatment: report of a task force of the American Society for Bone and Mineral Research. J Bone Miner Res 31(1):16-35

41. Black DM, Bauer DC, Schwartz AV, Cummings SR, Rosen CJ (2012) Continuing bisphosphonate treatment for osteoporosis-for whom and for how long? N Engl J Med 366(22):2051-2053

42. Black DM, Reid IR, Boonen S et al (2012) The effect of 3 versus 6 years of zoledronic acid treatment in osteoporosis: a randomized extension to the HORIZON-Pivotal Fracture Trial (PFT). J Bone Miner Res 27:243-254

43. Clayton MJ (1997) Delphi: a technique to harness expert opinion for critical decision-making tasks in education. Educ Psychol 17(4):373-386

44. Bodmer NS, Häuselmann HJ, Frey D et al (2019) Expert consensus on relevant risk predictors for the occurrence of osteoporotic fractures in specific clinical subgroups - Delphi survey. BMC Rheumatol 3:50

45. McArthur C, Hillier L, loannidis G, Adachi J, Giangregorio L, Hirdes J, Papaioannou A (2020) Developing a fracture risk clinical assessment protocol for long-term care: a modified Delphi consensus process. J Am Med Dir Assoc S1525-8610(20):30705-30702. https://doi.org/10.1016/j.jamda. 2020.08.015

\section{Publisher's Note}

Springer Nature remains neutral with regard to jurisdictional claims in published maps and institutional affiliations.

\section{Submit your manuscript to a SpringerOpen ${ }^{\circ}$ journal and benefit from:}

- Convenient online submission

- Rigorous peer review

- Open access: articles freely available online

High visibility within the field

- Retaining the copyright to your article

Submit your next manuscript at $\boldsymbol{\nabla}$ springeropen.com 